\title{
Revisão taxonômica das espécies amazônicas de Rhizophoraceae
}

Ghillean T. Prance ('), Marlene Freitas da Silva $\left({ }^{2}\right)$, Byron Wilson Albuquerque $\left({ }^{3}\right)$, Izonete de Jesus da Silva Araújo ( $\left.{ }^{3}\right)$, Léa Maria Medeiros Carreira ( $\left.{ }^{3}\right)$, Marilene Marinho Nogueira Braga $\left({ }^{3}\right)$, Miramy Macedo $\left({ }^{3}\right)$, Pedro Nonato da Conceição ( ${ }^{3}$ ), Pedro Luiz Braga Lisbôa $\left({ }^{3}\right)$, Pedro Ivo Braga $\left({ }^{3}\right)$, Regina Célia Lobato Lísbôa ( ${ }^{3}$ ) e Raimunda Conceição Queiroz Vilhena ( ${ }^{3}$ )

\section{Resumo}

Estudo das Rhizophoraceas da Amazônia abrangendo 5 gêneros: Rhizophora, Cassipourea, Sterigmapetalum, Polygonanthus e Anisophyllea. Doze espécies dos referidos gêneros são estudadas e descritas. Novos taxa não foram encontrados, porém, diversos nomes foram colocados em sinonímia. Apresentada a descrição do pólen de algumas espécies.

\section{INTRODUÇÃo}

Durante o Curso de Botânica Tropical, na disciplina de Sistemática, realızamos em conjunto o estudo da família Rhizophoraceae, a fim de demonstrarmos os métodos e procedimentos de um estudo taxonômico. A escolha desta família entre várias outras não menos interessantes, deu-se em razão de ser Rhizophoraceae uma família razoavelmente pequena, com diversos gêneros, e larga distribuição por toda a Amazônia, ocupando habitats os mais diversos, desde o mangue até a mata da terra firme. Devemos ressaltar também que desde o trabalho de Engler (1876), não houve ou'ra revisão nos gêneros amazônicos, a não ser as interessantes observações de Pires \& Rodrigues (1971), sobre os gêneros Polygonanthus e Anisophyllea.

Rhizophoraceae é uma família constituída de 16 gêneros com cerca de 120 espécies distribuídas nas regiões tropicais e subtropicais do mundo, com apenas 5 gêneros representados na região amazônica.
Em Rhizophoraceae o gênero típico e mais conhecido é Rhizophora ou mangue, típica desse habitat, havendo porém vários gêneros da família que habitam as matas altas longe do mar.

\section{RHIZOPHORACEAE R. Brown $\left({ }^{4}\right)$}

Rhizophoraceae R. Brown, Gen. Rem. in Flinders, Voy. Terr. Austral. 2: 549. 1814; in Tuckey, Narr. Zaire Cong. : 437. 1816; De Candolle, Prodromus 3: 31. 1828; Endlicher, Gen. Pl. : 1184. 1840; Benth. \& Hook. Gen. P1. 1:677-683. 1865; Engler, Mart. Fl. Bras. 12 (2) : 424-432. 1876.

Arvores ou arbustos. Folhas simples, inteiras, opostas, alternas ou verticiladas, pecioladas, glabras ou com pelos simples, às vezes com pontuações negras. Estípulas presentes, pequenas ou grandes, interpeciolares, axilares, caducas. Inflorescências em panículas, rácemos especiformes, cimeiras ou corimbos dicótomos, fasciculadas ou de flores solitárias, axilares, ou extraxilares. Flores actinomorfas, bissexuais ou unissexuais por aborto, monóicas, dióicas ou polígamas; disco presente, raro ausente; sépalas $4-7$, mais ou menos unidas na base, valvares, persistentes; pétalas do mesmo número das sépalas, geralmente menores, de ápice inteiro, lobado, laciniado, fimbriado ou esterigmiforme; estames 8-40, freqüentemente dispostos em pares opostos às pétalas, inseridos na margem externa de um disco, ou raro coalescentes na base (Sterigmapetalum); filetes em geral curtos; anteras in-

(1) - Instituto Nacional de Pesquisas da Amazônia e B. A. Krukoff, Curator of Amazonian Botany, the New York Botanica! Garden.

( 2 ) - Instituto Nacional de Pesquisas da Amazônia e bol sista do CNPq.

(3) - Alunos do Curso de Botânica Tropical do INPA.

(4) - Por Byron W. P. de Albuquerque. 
trorsas, rimosas, dorsifixas ou não; ovário súpero, semi-súpero ou ínfero, 2-6 locular, lóculo uni ou bi-ovulado; óvulo anátropo, pêndulo, placentação axilar; estígma papiloso, bilobado, 3-4 lobado, capitado, 5-6 radiado ou em forma de disco hipógino pela dilatação dos estiletes na base. Fruto drupa, baga ou cápsula; semente 1-2 por lóculo.

Família de 16 gêneros e aproximadamente 120 espécies, com distribuição pantropical nas regiões tropicais e subtropicais, dos quais 5 estão representados na Amazônia.

\section{CHAVE PARA OS GENEROS AMAZÔNICOS DE RHIZOPHORACEAE}

1. Folhas opostas ou verticiladas; estilete 1. Secção RHIZOPHOREAE.

2. Ovario infero; folhas opostas; fruto germinando na árvore; raízes escoras presentes; planta de mangue.

\section{Rhizophora}

2. Ovario súpero; folhas opostas ou verticiladas; fruto germinando no chão; sem raízes escoras; planta da mata.

3. Folhas opostas; pétalas espatuladas, com apêndices, infiorescência séssıl, axilar.

\section{Cassipourea}

3. Folhas verticiladas; pétalas laciniadas; inflorescência pedunculada.

1. Folhas alternas; estiletes 3-4.

3. Sterigmapetalum

\section{Secção ANISOPHYLLEAE}

4. Pétalas não laciniadas; fruto obcônico, coriáceo, com 4 alas.

\section{Polygonanthus}

4. Pétalas com a metade superior 3-laciniada; fruto globoso, endocarpo ósseo, sem alas.

\section{Anisophyllea}

\section{Rhizophora Linn. $\left({ }^{5}\right)$ (Mapa 1)}

Gen. Plantarum ed. 1: 137. 1737, ed. 5: 212. 1754; Linn., Sp. Plantarum: 443. 1753; De Candolle, Prodr. 3: 32. 1828; Benth. \& Hook., Gen. Pl. 1: 679. 1865; Engler, Mart. F1. Bras. 12 (2) : 425-427. 1876.

HÁвITO -- Árvores ou arbustos das terras litorâneas com numerosas raízes tipo escora, descendo dos ramos.
ESTÍPULAS - Grandes, interpeciolares, foliáceas, caducas.

FOLHAS - Opostas, pecioladas, coriáceas, persistentes.

INFLORESCENACTA - Auxiliar em cimeira dicotômica, ou flores solitárias, com brácteas.

FLORES - Hermafroditas, actinomorfas, 2 bractéolas com disco grande; sépalas 4, lanceoladas, grossas, coriáceas, persistentes, prefiloração valvar; pétalas 4, coriáceas, lanceoladas valvares, caducas, iguais ou menores que as sépalas, margem vilosa; estames $8-12$, epipétalos; filetes muito curtos; anteras longas, lanceoladas, deiscência longitudinal, introrsa; carpelos 2, gamocarpelar; ovário ínfero; lóculos 2, cada lóculo com 2 óvulos; placentação axilar, óvulo anátropo, pêndulo; estilete cônico, delgado, bi-sulcado; estígma bilobado.

FRUTO - Baga coriácea, sépalas persistentes, com uma loja; semente 1, (raramente 2), ovóide, endosperma ausente; embrião germinando dentro do fruto ainda na planta-mãe; radícula muito grande, perfurando a parte superior do fruto.

DISTRIBUIÇÃo GEOGRÁFICA E HABITAT Flórida (Costa, Centro e Sul), Cayos Bermuda, Antilhas (exceto Dominicana), Trinidad, Tobago e Bonaire, Curaçao e Aruba. Desde o México até o Equador. Nordeste do Brasil até Peru, ilhas Galapagos, Africa, Melanésia e a Polinésia. Abundante nos mangues, águas pantanosas salgadas e salobras.

\section{ESPÉCIE TÍPICA - Rhizophora mangle L.}

OBSERVAÇõES - Três foram as espécies Americano-Atlânticas reconhecidas por Leechman (1915). As mesmas espécies também ocorrem, segundo Keay (1953), na Africa Ocidental. Os taxa embora muito próximos, apresentam pequenas diferenças na ecologia. Todas três espécies foram incluídas por Ding Hou (1960), na revisão do gênero Rhizophora. Breteler (1969) mostrou nitidamente que a espécie $R$. harrisonii é intermédia entre as espécies $R$. mangle e $R$. racemosa na morfologia e na ecologia. Ele mostrou também que a fertilidade do pólen de $R$. harrisonii é menor do que nas outras duas espécies, e considerou

(5) - Por Pedro Nonato Conceição, Pedro Braga Lisboa e Regina C. Lobato Lisbôs. 
R. harrisonii como híbrida das espécies: $R$. mangle e $R$. racemosa, conclusão esta que é provavelmente correta. Então, incluimos aqui as três espécies, porque todas elas são encontradas na região estuarina da Amazônia.

\section{CHAVE PARA IDENTIFICAÇÃO DAS' ESPÉCIES DE RHIZOPHORA DO BRASIL}

1. Inflorescência ramificada, muitas flores; pedicelos $3-11 \mathrm{~mm}$; radícula de $15-65 \mathrm{~cm}$.
2. Radícula de 25 até $65 \mathrm{~cm}$; estígmas 2,3 raramente 4 ; botão floral e pedúnculo mais espesso; pedicelos $3-5 \mathrm{~mm}$.

1. R. racemosa

2. Radícula de 15 até $30 \mathrm{~cm}$; estígmas sempre 2; botão floral e pedúnculo menos espessos; pedicelos $3-11 \mathrm{~mm}$.

\section{R. harrisonit}

1. Inflorescência simples, poucas flores $(2,3$ até 4); radícula até $30 \mathrm{~cm}$; pedicelos $7-20 \mathrm{~mm}$; radicula $15-20 \mathrm{~cm}$.

3. R. mangle

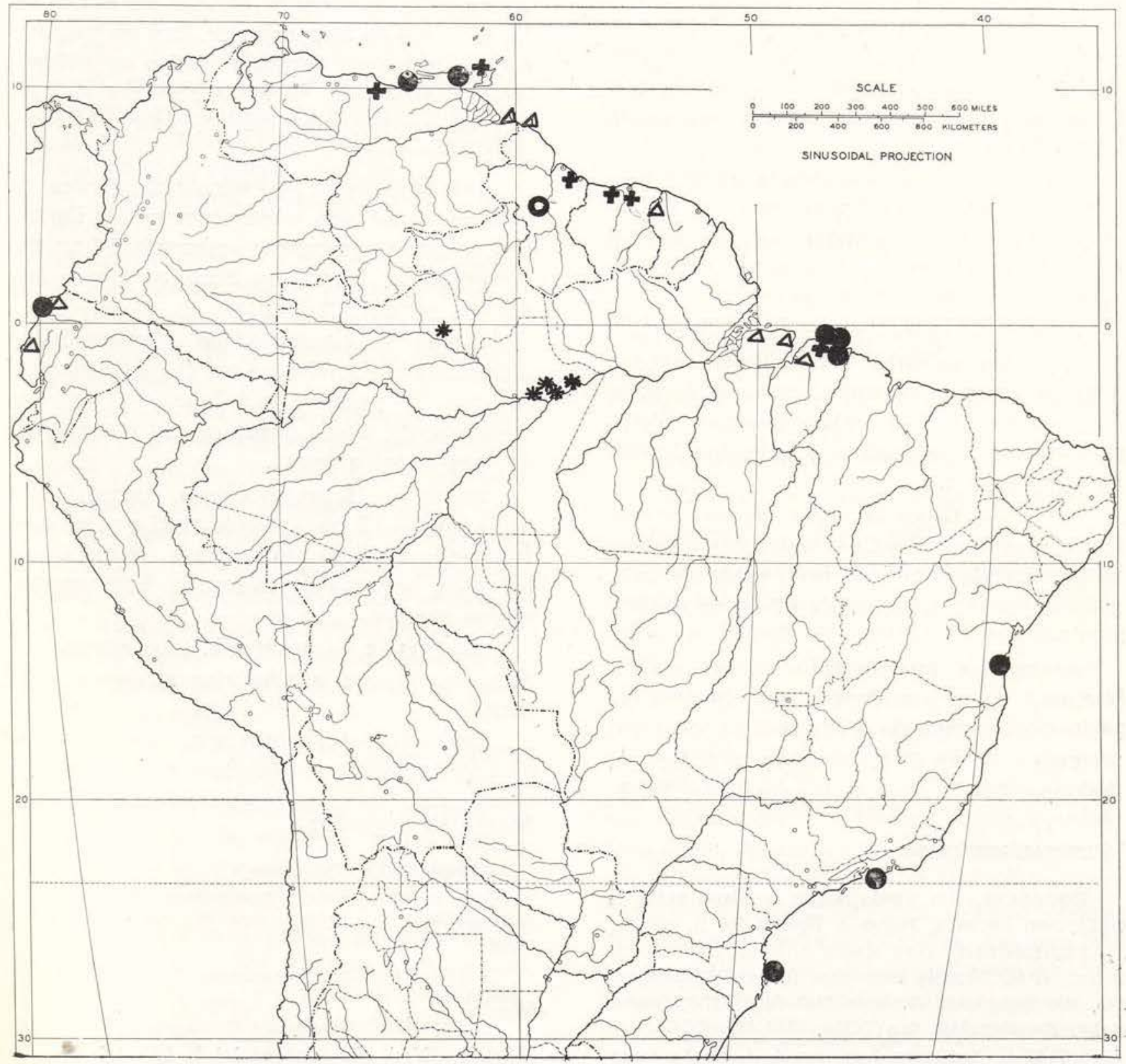

Mapa 1. Distribuição dos gêneros Rhizophora e Anis ophyllea. mosa (amostras estudadas, a distribuição é mais ampla). *, A. manausensis; O, A. guianensis. 


\section{Rhizophora racemosa G. F. W. Meyer}

Prim. Fl. Essequib. : 185. 1818; Leechman, Kew Bull. 1918 : 6. 1918; Keay, Kew Bull. 1953 : 125. 1953.

Rhizophora mangle L. var, racemosa (G. F. W. Meyer) Engler, Mart. Fl. Bras. 12 (2) : 427. 1876.

на́втто - Árvores de até $16,5 \mathrm{~m}$ por $20 \mathrm{~cm}$ de diâmetro a $3 \mathrm{~m}$ de altura, raízes nascendo no fuste desde $2,5 \mathrm{~m}$ de altura para baixo, casca marrom-amarelada.

FOLHAS - Simples, opostas, com estípulas, elíticas, limbo de $9-15 \mathrm{~cm}$ de comprimento por $3-5 \mathrm{~cm}$ de largura, nervação camptódromo-broquidódroma; base aguda a obtusa; ápice agudo, verde-escura no ventre, verde-amarelada no dorso, com lenticelas bem visíveis; pecíolo de 2-3 cm de comprimento.

INFLORESCENCIA - Panícula axilar, dicotômica, 5-6 vezes ramificada, com muitas flores, 4-11 cm de comprimento; pedunculo 1.5$6 \mathrm{~cm}$ de comprimento; bractéolas espessas, irregularmente lacerado-dentadas.

FLORES - Hermafroditas, sépalas e pétalas 4 , pilosas, valvares; botão elitico, espesso e ápice pouco acuminado; estames 8 , conados; estígma bífido; ovário súpero inserido num disco; pétalas caducas; pedicelos $3-5 \mathrm{~mm}$ de comprimento.

FRUTO - Drupa coriácea, sépalas persistentes; semente 1, ovóide, endosperma ausen'e, yerminando dentro do fruto antes de cair; radícula pendente, longa, até $65 \mathrm{~cm}$ de comprimento.

HABITAT E DISTRIBUIÇÃo GEOGRÁFICA Mangue. Ocorre na América, porém, é a espécie mais comum da Africa.

TIPo - Herb G. F. W. Meyer 226, Guiana, (holótipo, GOET).

\section{Material estudado}

EQUADOR. Rio Verde, Little \& Dixon $21219 \mathrm{fl}$. (NY); San Lorenzo, Játiva \& Epling 810 fl. (NY).

VENEZUELA. Terr. Delta Amacuro: Missão de Guayo, J. G. Wessels Boer 1832 fl. fr. (NY); Monagas, Rio San Juan, Breteler 5163 fl. (COL); Guarapiche, Breteler $5151 \mathrm{fr}$. (COL), $5164 \mathrm{fr}$. (COL).

GUIANA." Acqueero Landing, J. S. de La Cruz 1089 fl. (NY).

GUIANA FRANCESA. Dep. Florestal 7731 fl. fr. (NY).
BRASIL. Pará: Ilha de Mosqueiro, E. P. Killip \& A. C. Smith 30478 fl. fr. (NY); Ilha das Onças, J. Huber MG 3845 fl. (INPA, MG); Breves, Vila Nova do Aramá, P. Cavalcante 2034 fl. (MG 35828).

\section{Rhizophora harrisonii Leechman}

Kew Bull. 1918 : 8. 1918; Keay, Kew Bull. 1953 : 124-125. 1953.

HÁBITO - Árvore com $20 \mathrm{~m}$ de altura, com raízes aéreas.

Folmas - Elíticas, $11-15 \mathrm{~cm}$ de comprimento, $4-7 \mathrm{~cm}$ de largura, margem inteira, ápice agudo, base cuneada, glabras em ambas as faces, verde na face superior, com pontuações negras dispersas; nervação do tipo camptódromo-broquidódroma, nervuras secundárias muito finas; pecíolo subcilíndrico, glabro, $1-2,5 \mathrm{~cm}$ de comprimento.

INFLORESCÊNCIA - Panícula dicotômica, 3 -5 vezes, ramificada, axilar, com muitas flores, $5-12 \mathrm{~cm}$ de comprimento; pedunculo $2-7 \mathrm{~cm}$ de comprimento; bractéolas mais ou menos espessas, geralmente bífidas.

FLORES - Hermafroditas, actinomorfas, apopétalas, diclamídeas, $1 \mathrm{~cm}$ de comprimento; estames 8; pedicelo cilíndrico, $3-11 \mathrm{~mm}$ de comprimento; botão ovado ou um pouco elítico, com o ápice agudo.

FRUTO - Ovato-lanceolado, rugoso, inflado; $4 \mathrm{~cm}$ por $1,5 \mathrm{~cm}$; radícula $11-25 \mathrm{~cm}$ de com. primento, alongada, ferruginosa. Semınte 1, alongada, germinando dentro do fruto, endosperma ausente.

HABITAT E DISTRIBUIÇÃo GEOGRÁFICA Mangue. Ocorre na América e Africa Ocidental.

TIPo - A. Leechman s/n., Guiana, perto de Georgetown, fl. fr. (holótipo, K; foto, INPA) .

\section{MAterial estudado}

VENEZUELA. Monagas, rio San Juan acima de Caño la Brea, J. G. Wessels Boer 1827 fl. (NY), Breteler 4687 fl. (COL), 5166 fl. (COL), 5168 fr. (COL).

TRINIDAD. Coroni swamps, Taylor $12633 \mathrm{fl}$. (NY).

SURINAME. Saramacca R., Maguire \& Stahel 23600 fl. (INPA, NY), Jonker 600 fl. (NY); Suriname R., Florschütz 910 fl. (NY).

GUIANA. Leechman $\mathbf{s} / \mathbf{n}$ fl. (NY provável isótipo), Demerara Rio, Jenman 4382, fl. (NY). 


\section{Rhizophora mangle Linn.}

Sp. Pl. 1 : 443, 1753, Gen. Pl. ed. 5:212, 1754; Jacquin, Select. Stirp. Amer. : 141. t. 89. 1763; Vellozo, Fl. Flum. t. 1. 1825; Engler, Mart. Fl. Bras. 12 (2): 426-427. 1876; Leechman, Kew Bull. 1918: 4. 1918. Keay, Kew Bull. 1953: 123-124. 1953.

на́вIто - Árvore pequena, 4-7 $\mathrm{m}$ de altura. Casca roxa ou rosea internamente, ligeiramente amarga.

FOLHAS - Opostas, elíticas; pontuações negras distribuídas uniformemente na face inferior, $8-14 \mathrm{~cm}$ de comprimento, $4-7 \mathrm{~cm}$ de largura, margem inteira, ápice agudo, base cuneada; glabra em ambas as faces, verde na face superior; nervação do tipo camptódromo-broquidódroma, 10-12 pares de nervuras secundárias, proemirientes na face inferior, promínulas na face superior; pecíolo 1,5-2,5 cm de comprimento, ligeiramente aplanado, glabro, sem glândulas.

INFLORESCÊNCIA - Em grupos de 4 flores, axilar, sem ramificação ou somente até duas vezes ramificada, $4-9 \mathrm{~cm}$ de comprimento; pedúnculo $1,7-9 \mathrm{~cm}$ de comprimento; bractéolas delgadas, bífidas.

FLORES - Apopétalas, diclamídeas, 0,8$1 \mathrm{~cm}$ de comprimento; sépalas persistentes, estames 8, pedicelos 6-22 $\mathrm{mm}$ de comprimento.

FRUTO - Glabro, castanho-escuro, 1,5$3 \mathrm{~cm}$ de comprimento; $1-1,5 \mathrm{~cm}$ de diâmetro, persistente nos ramos, contendo cada uma plântula em desenvolvimento, com uma radicula de $15-30 \mathrm{~cm}$ de comprimento por $0,4-1 \mathrm{~cm}$ de largura, de cor verde, extremidade aguda. Ao cair, flutua nas águas do rio e mar antes de se fixar na terra.

FENOLOGIA - Floresce e frutifica durante 0 ano todo.

DISTRIBUIÇÃo GEOGRÁFICA E HABITAT Mangue. Ocorre na América, Africa ocidental e algumas ilhas do Pacífico (Nova Caledonia, Fiji, Tonga, etc.).

usos - Usa-se a madeira na forma roliça para moirão de cercas; também é excelente combustível. A casca é utilizada para curtir couros. As folhas sã̃o ricas em tanino.

TIPO - Sloane $s / n$., Jamaica, (Herb. Sloane $V^{\prime} l: 62$, lectotype, BM).

\section{MATERIAL ESTUdAdo}

EQUADOR. Esmeralda, E. Little \& Dixon 21161 fl. fr. (NY).

COLOMBIA, Magadelena, Isla de Salamanca. R. Romero C. 10527 fr. (COL).

VENEZUELA. Peninsula Paraguaná, F. J. Breteler 4343 fl. (MG); Monagas, rio San Juan, Breteler 4682 fl. (COL); Peninsula de Paria, Breteler 5172 fl. (COL), $5173 \mathrm{fl}$. (COL).

BRASIL. Pará: Belém, Ilha das Onças, J. Huber MG 3845 fl. (INPA, MG); Costa de Quatipuru, J. Huber MG 1756 fr. (INPA, MG); Salinópolis, A. Ducke MG $895 \mathrm{fr}$. (MG), W. A. Egler $600 \mathrm{fl}$. (MG 22605), G. T. Prance 20209 fl. fr. (INPA, NY); São Caetano de Odivelas, Rito 6 fr. (MG 41838); Bragan. ça, Museu Goeldi 9819 fr. (MG); Bahia: Maraú: R. P. Belém 3481 fl. (NY); Maranhão: Itha de Maranhão, Anil, A. Ducke MG 393 fl. (MG); Rio de Ja. neiro: Ilha da Madeira G. Pabst 6320 fl. fr. (HB, NY). Santa Catarina: Itacorubi, Reitz 6054 fl. (NY).

\section{Cassipourea Aublet ( ${ }^{6}$ )}

Pl. Guiane I: 529, t. 211. 1775; De Candolle, Prodromus 3: 32, 1828; Benth. \& Hook., Gen. Pl. 1: 679. 1865; Engler, Mart. Fl. Bras. 12 (2): 429. 1876.

Legnotis Swartz, Prodr. Fl. Ind. Occ. : 84. 1788.

Tita Scopoli, Introd. : 219. 1777.

HÁBITO - Árvore ou arbusto.

ESTÍPULAS - Interpeciolares, caducas.

FOLHAS - Opostas-decussadas.

INFLORESCÊNCIA - Com fiores axilares, solitárias ou fasciculadas, sésseis ou pediceladas, pedicelos articulados, brácteas presentes.

FLORES - Hermafroditas, com brácteas pequenas na base do pedicelo; disco carnoso ou membranáceo, dentado; cálice tubuloso, campanulado, 4-5 (7) lacínias triangulares, curtas, eretas, valvares; pétalas 4-5, unguiculadas, fimbriadas, branco-veludosas, dobradas no botão; estames numerosos, 8.40 , inseridos no bordo do disco; anteras oblongas, rimosas longitudinalmente, dorsifixas, introrsas; carpelos uni ou bicarpelar; ovário súpero, globoso-ovóideo, livre, inserido no fundo do cálice, sericeo-piloso, 2-4 lóculos; óvulos 2 por lóculo, anátropos pêndulos; estilete filiforme ereto; estígma dilatado, 3-4 lobado ou capitado.

(6) - Por Marlene Freitas da Silva, Léa Medeiros Carreira e Miramy Macêdo. 
FRUTO - Cápsula ovóide, subcarnosa, 3-4 lóculos; sementes 1 ou raramente 2 por lóculo, pêndulas, triangulares ou oblongo-elíticas, testa coriácea, arilada, escariosa; embrião reto, cotilédone plano, radícula ereta.

DISTRIBUIÇÃo GEOGRÁFICA - América tropical, Brasil boreal, Guiana até India ocidental, Sul da África e Madagascar.

ESPÉCIE TÍPICA - Cassipourea guianensis Aubl.

\section{CHAVE PARA IDENTIFICAC̣ÃO DAS ESPÉCIES AMAZONNICAS DE CASSIPOUREA}

1. Flores pediceladas, pedicelos $2-6 \mathrm{~mm}$ longos.

1. Flores sésseis.

$$
\text { 1. C. peruviana }
$$

2. Cálice densamente viloso externamente; nervura mediana vilosa; estípulas grandes,
$5-12 \mathrm{~mm}$ de comprimento por $4-7 \mathrm{~mm}$ de largura.

\section{C. lasiocalyx}

2. Cálice esparsamente viloso externamente; nervura mediana glabra ou com pouco pelos; estípulas pequenas, $4,5 \mathrm{~mm}$ de comprimento.

\section{C. guianensis}

\section{Cassipourea peruviana Alston (Mapa 2)}

New Bull. $1925: 268.1925$

Cassipourea ulei Briquet, Candollea 4: 347. 1931. Tipo: Ule 9638, Bolívia, Cobija, fl. (holótipo, G; isótipos, MG 14476, NY; foto, INPA).

HÁBIto - Árvore até $15 \mathrm{~cm}$ de altura.

FolHas - Pecioladas, lanceoladas e elíticas, subcoriáceas $4,5-16 \mathrm{~cm}$ de comprimento por $2-5 \mathrm{~cm}$ de largura; glabras e ligeiramente lustrosas na face superior, na face inferior com

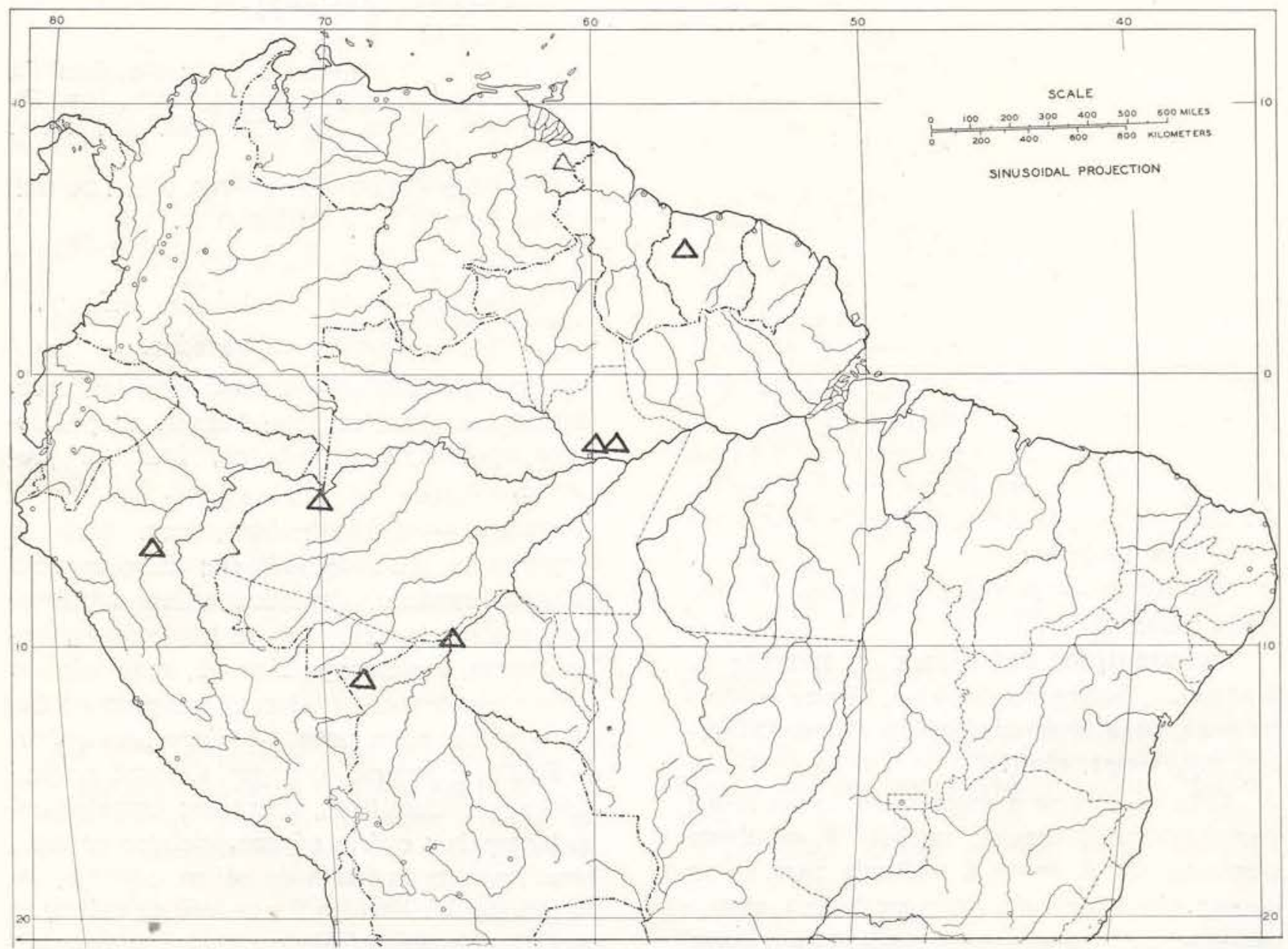

Mapa 2. Distribuição de Cassipourea peruviana. 
poucos pelos; pelos mais freqüentes sobre a nervura principal, poucos sobre as outras nervuras; margem inteira, ápice acuminado, base cuneada ou obtusa; nervação do tipo comptódromo-broquidódroma, com 6-12 pares de nervuras secundárias submersas na face superior, promínulas na inferior; pecíolo $3-6 \mathrm{~mm}$ de comprimento, subcilíndrico, plano na parte ventral, piloso, sem glândulas.

INFLORESCÊNCIA - Em glomérulos axilares, curto-pediceladas.

FLORES - Hermafroditas, pediceladas; botões globosos, 3-5 mm de comprimento, subglabros externamente, estipitados, estipe $1 \mathrm{~mm}$ de comprimento; pedicelo cilíndrico, $2-6 \mathrm{~mm}$ de comprimento, articulado na inserção com a flor; cálice gamosépalo, 4-5 laciniado no ápice, lacínias triangulares, ápice agudo, subglabro externamente, internamente denso piloso; pétalas 5, pilosas, dobradas no botão; estames muitos, soldados apenas na base em uma membrana, envolvendo o ovário; anteras com 2 tecas, de deiscência longitudinal, rimosa, dorsifixas; ovário súpero, estipitado, sobre um disco delgado, subgloboso, densamente piloso externamente, até o estilete; estilete curto e espesso no botão, $1 \mathrm{~mm}$ de comprimento, cilíndrico; estígma glabro, capitado.

FRUTO - Desconhecido.

HABITAT E DISTRIBUição GEOGRÁFICA Mata da terra firme. Ocorre na Amazônia, Colômbia e Guianas.

TIPo - Spruce 4005, Peru, Tarapoto, fl. (isótipos, G, NY; foto, INPA).

\section{Material ESTUdAdo}

SURINAME. Tafelberg, B. Maguire $24661 \mathrm{fl}$. (INPA, NY), 24723 fl. (INPA, NY).

COLÔMBIA. Caquetá, Sucre, J. Cuatrecasas 9054 fl. (COL).

BRASIL. Território de Rondônia: Norte do Rio Madeira, $2 \mathrm{~km}$ em baixo do rio Abună, G. T. Prance et alii 8349 fl. (INPA 25147, NY); Amazonas: Estrada Manaus-Itacoatiara, $\mathrm{km} \mathrm{70}$, Osmarino Monteiro S/n (INPA 27362); $\mathrm{km} \mathrm{79,} \mathrm{L.} \mathrm{\&} \mathrm{D.} \mathrm{Coelho} 26$ fl. (INPA 27974); Esperança, boca do rio Javari, A. Ducke 877 fl. (INPA 16427: MG 18783).

Os espécimes de Cassipourea com pedicelos longos ou com pubescência no pedicelo, foram anteriormente reconhecidos por outros autores como espécies diferentes. Entre $C$. peruviana e $C$. ulei por exemplo, não reconhecemos nenhuma diferença nos tipos, no tamanho das folhas, do pedicelo ou mesmo ocorrência de pelos.

$\mathrm{O}$ interessante é que, existem muitos pares de espécies relacionados nos gêneros Amazônicos de muitas famílias, com ocorrência um ne terra firme, e outro na várzea como por exemplo as espécies de Cassipourea: C. guianensis que ocorre na terra firme e $C$. peruviana que ocorre na várzea.

\section{Cassipourea lasiocalyx Alston}

Kew Bull. 1925 : 269. 1925.

TIPo - Jenman 4051, Guiana, Demerara River.

oBsERVAÇÃo - Material não estudado.

\section{Cassipourea guianensis Aublet (Mapa 3)}

Pl. Guiane 1: 529, t. 211. 1775; De Candolle; Prodromus 3: 34. 1828; Engler, Mart. F1. Bras. 12(2) : 429-430. 1876; Alston, Kew Bull. 1925: 269-270. 1925 .

Legnotis cassipourea Swartz, Fl. Ind. Occ. 2: 970. 1800 .

Cassipourea macrophylla DC, Prodr. 3: 34. 1828.

Cassipourea serrata Benth., Hook. Jour. Bot. 2: 233.1840 .

Cassipourea guianensis var. serrata (Benth.) Engl., Mart. Fl. Bras. 12(2) : 426. 1876.

Cassipourea quadrilocularis Spruce ex Engl., Mart. Fl. Bras. 12(2) : 426. 1876, nom. nud. in syn.

Cassipourea spruceana Benth. ex Engl., Mart. F1. Bras. 12(2) : 429. 1876; Alston, Kew Bull. 1925: 270. 1925. Tipo: Spruce 819, Pará, Santarém (isotipos, BM, M, MG, NY; foto, INPA).

на́вIто - Arvoreta até $6 \mathrm{~m}$ de altura.

FOLHAS - Elíticas a oblongo-lanceoladas, membranáceas a semi-coriáceas, $4,5-23,5 \mathrm{~cm}$ de comprimento por $2,5-9,5$ de largura, glabras na face superior, alguns pelos na nervura mediana da face inferior; ápice acuminado, base arredondada ou cuneada, margem inteira ou esparsamente serrilhada; pecíolo subcilindicro, subglabro, 3-10 mm de comprimento.

INFLORESCÊNCIA - Glomérulo axilar.

FLORES - Sésseis, hermafroditas, diclamídeas; cálice campanulado 4-5 lobado; externa- 
mente esparsamente piloso, internamente denso seríceo-viloso, $5 \mathrm{~mm}$ de comprimento; pétalas $4-5$, unguiculadas, fimbriadas, brancas, pilosas, espatuladas; estames numerosos (mais ou menos 20), inseridos no bordo externo do disco: lobos triangulares, $1.5 \mathrm{~mm}$ de comprimento; ovário súpero, globoso, livre no fundo do receptáculo, trilocular, denso piloso externamente; estilete filiforme ereto; estígma capitado.

FRUTO - Curto-pedicelado; pedicelo $2 \mathrm{~mm}$ de comprimento, piloso; com uma bráctea na base.

HABITAT E DISTRIBUição GEOgRÁFICA Mata da várzea e margem dos igarapés. Ocorre em Venezuela, Trinidad, as Guianas e Amazônia. (BM).

TIPO - Aublet $s / n$., Guiana Francesa,

\section{Material estudado}

VENEZUELA. Monagas: Guarapiche, F. J. Breteler 5124 fl. (COL, VEN.); Terr. Amazonas: rio Orinoco, rio Cuao, B. Maguire et alii $29026 \mathrm{fl}$. (INPA, NY); rio Cunucunuma, B. Maguire et alii 30394 fl. (INPA, NY); Bolívar: El Paraíso, F. J. Breteler $5061 \mathrm{fl}$, (COL); Altiplanicie de Nuria,
Steyermark 89006 fl. (COL. VEN.); Terr. Delta Amacuro: este nordeste de El Palmar, L. M. Berti 78 fl. (COL.), 114 fl. (COL, VEN.).

GUIANA, Rio Demerara, J. S. de La Cruz 2495 f1. (NY); rio Wanama, J. S. de La Cruz 4002 fl. (NY).

SURINAME. Rio Marawyne, Wullschlaegel 800 f1. fr. (NY); Rio Saramacca, B. Maguire $23933 \mathrm{fl}$. (INPA, NY).

GUIANA FRANCESA. St. Laurent, R. S. Cowan 38920 fl. (COL.).

BRASIL. Amazonas: Manaus, cachoeira baixa do Tarumā, W. Rodrigues et al. $4943 \mathrm{fl}$. fr. (INPA 13475), G. T. Prance et al 3862 fr. (COL, INPA 19486, MG, NY); entrada do Paracuúba, próximo de Manaus, fl. fr. W. Rodrigues \& L. CoeTho $2562 \mathrm{fl}$. fr. (INPA 9098); Manaus, igarapé Mindu, A. Ducke s. n. fl. (INPA 16435); baixo rio Negro, G. T. Prance et al 2647 fl. (INPA 18198, MG, NY), W. Rodrigues \& L. Coêlho 2146 fl. fr. (INPA, 8527); Manaus, Estrada Mauá, G. T. Prance et al 11583 fl. fr. (INPA, MG, NY); Manaus, Enseada Grande, Ponta Negra, W. Rodrigues \& J. Lima 2209 fl. fr. (INPA 8598); Estrada Manaus-Porto Velho, L. Coêlho $141 \mathrm{fl}$. (INPA 35173); Camanaus, alto rio Negro, P. Cavalcante 594 fl. (MG), W. Rodrigues 868 (INPA, 7104); Manaus, R. Spruce $\mathbf{s} / \mathbf{n}$ fl. (BM, MG). Pará; Peixe-Boi, J. Huber MG 7804 fl. (INPA 12432, MG), São Miguel do Guamá, A. Goeldi MG 7789 fl. (INPA 12441, MG); Marajó, Maguari, J. Huber MG 300 fl. (MG); Belém-Brasília, Km 92.

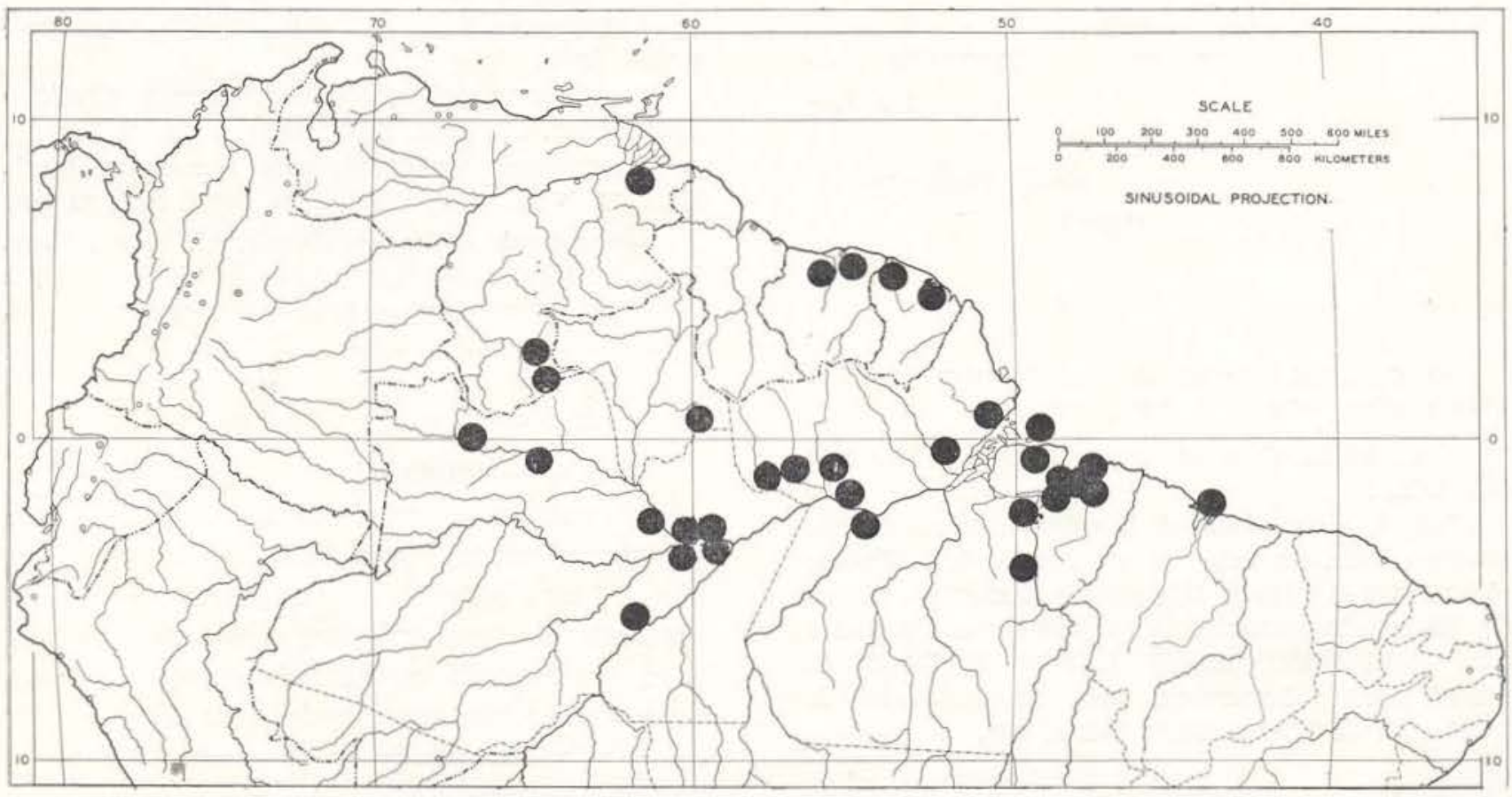

Mapa 3. Distribuição de Cassipourea guianensis. 
W, A. Egler 1171 fl. (INPA 12440, MG), M. Kuhl. mann \& S. Jimbo 283 fl. (MG, SP), Maguire et alii $56028 \mathrm{fl}$. (INPA, NY); ilha Mexiana, Fazenda Nazaré, M. Guedes MG 2301 fl. (INPA 12431, MG); Marajó, Aramá, J. Huber MG 1884 fl. (INPA 12435, MG); Bragança, Colônia Benjamim Constant, Museu Goeldi MG $9768 \mathrm{fl}$. (INPA 12434, MG); Belém, J. M. Pires \& G. A. Black 459 fl. (IAN, INPA 4708), $829 \mathrm{fl}$. (COL, IAN); Santa Izabel, Museu Goeldi, MG $9710 \mathrm{fl}$. (INPA 12436, MG); Sem localidade, Burchell $9673 \mathrm{fl}$. (NY); baía do Sol, Mosqueiro, P. Cavalcante \& M. G. Silva 1826 fl. (MG); estrada Bragança-Viseu, $\mathrm{km} 15$ além do rio Piriá, P. Cavalcante $1863 \mathrm{fl}$. (MG); rio Trombetas, cachoeira Porteira, A. Ducke MG 8952 fl .(MG); Santarém, rio Maicá, serra de Taperinha, M. G. Silva 1410 fl. (MG); Igarapé-açú, R. S. Rodrigues MG 3355 est. (MG); alto Ariramba, A. Ducke MG 14935 f!. (MG); Cametá, R. S. Rodrigues MG 3794 fl. (MG); Marapanim, igarapé Água Boa, M. G. Silva 493 fl. (MG); Collares, A. Ducke MG 12649 fl. (MG), rio Mapuera, cachoeira Caraná, A. Ducke MG 9056 fl. (MG); rio Mapuera, Escola, A. Ducke MG 9010 fl. (MG); Óbidos, A. Ducke MG 6958 fl. (INPA 12433, MG) Terr. do Amapá: rio Mururé, J. M. Pires $50455 \mathrm{fl}$. (INPA, MG, NY) 50647 fl. (INPA, MG, NY); rio Araguari, W. A. Egler \& H. S. Irwin 46584 fl. (INPA MG, NY); rio Araguari, Capoeira do Rei, W. A. Egler 659 fl. (MG 22619). Maranhão: ilha do Maranhão, Anil, A. Ducke MG 376 fl. (INPA 12437, MG).

OBSERVAÇÕEs - Cassipourea guianensis, mostra uma nítida variação na forma, consistência e margem da folha. Isto vinha causando dúvidas quanto à denominação exata da planta em virtude das divergências nomenclaturais antes mostradas por diversos botânicos, como: depois de descrita por Aublet (1775), Dentham (1840) baseado nessas variações criou uma nova espécie, Cassipourea serrata, mais tarde colocada por Engler (1872) como variedade de $C$. guianensis - variedade serrata. Alston (1925) concluiu de seus estudos sobre o gênero, que Cassipourea serrata e Cassipourea guianensis eram a mesma espécie, e colocou-a como sinônimo desta última. Briquet (1931) observando os mesmos detaIhes restaurou as denominações antigas. Para melhor esclarecimento, constatamos através do "Diagrama pictórico de variação", (Gráficos 1 e 2), que realmente Alston estava certo em consıderá-las como uma só unidade taxonômi- ca, pois tais variações têm distribuiçōes difusa no diagrama.

Similarmente, há uma grande variação em outros caracteres como: tamanho, pubescência nas folhas e na parte externa do cálice. A análise destas variações indica pequena ou nenhuma individualização, nãj sendo assim consideradas taxonomicamente, como por €xemplo: a coleção Pires \& Black, 459 apresenta longas e persistentes estípulas; Prance 11583 apresenta maior densidade de pelos nos ramos, nervura principal, margem das folhas, porém, há ainda a considerar as variações no tamanho e condição caduca das estípulas e das folhas glabras divergindo completamente da espécie colhida por Prance 11583. Há também uma grande variação no tamanho do pecíolo - alguns exemplares do Estado do Pará têm pecíolos curtíssimos ou folhas subsésseis, como no tipo de $C$. spruceana, espécie esta baseada unicamente no pecíolo curto e por esta razão considerada também como sinônimo de $C$. guianensis .

3. Sterigmapetalum Kuhlmann ( ${ }^{7}$ ). (Mapa 4) Arch. Jard. Bot. Rio de Janeiro, 4: 359. 1925.

HÁBITo - Árvore pequena ou grande.

ESTíPulas - Presentes, interpeciolares, ou axilares, coriáceas.

FOLHAs - 2-5 verticiladas, curto-pecioladas, coriáceas, persistentes, quando jovens frouaxmente furfuráceas, obovato-obtusas.

INFLORESCÊNCIA - Axilar, nas folhas superiores ou subterminal, em corimbos dicotômicos, longo-pedunculada; pedúnculos com bractéolas.

FLORES - Dióicas, actinomorfas; cálice em ambos os sexos valvares, nas flores masculinas, 6-7 dentado, nas femininas 5-6 dentado; pétalas nas flores masculinas lineares na base até o meio, inteiras, depois laciniadas, 3-partidas; estames 10-12; filetes com indumentos curtamente vilosos na base, sob os ovários rudimentares, mais ou menos coalescentes; anteras dorsifixas, introrsas, com àpice e base curtamente incisos; pétalas das flores femininas e masculinas semelhantes; es-

(7) - Por Byron W. P. de Albuquerque 


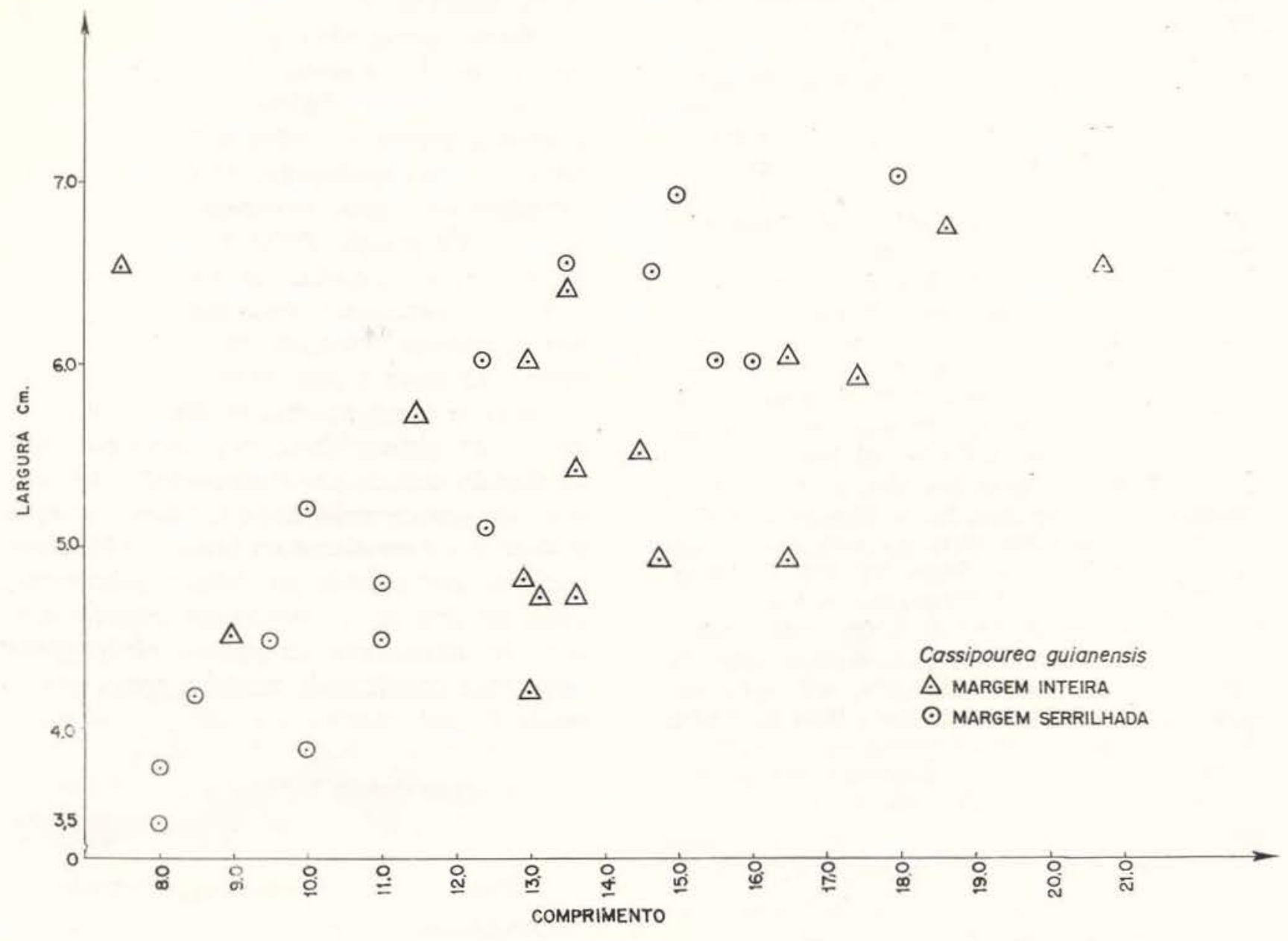

Gráfico. 1. Diagrama pictórico de variação de Cassipourea guianensis Aubl.: — Largura da folha, comprimento da folha e tipo da margem.

taminódios numerosos, hipóginos, escamiformes; ovário séssil, obovado, viloso, 5-6 locular, lóculos com 2 óvulos; óvulos pêndulos, estígmas sésseis, 5-6 radiado.

FRUTO - Cápsula obovado-oblonga, septifraga, 5-6 locular, lóculos com duas sementes; sementes colaterais, pêndulas, oblongas, com alas oblongo-falciformes no ápice, apendiculadas ou alongadas, alas com núcleo articulado, caducíssimas; endosperma pouco espesso. oleaginoso; radícula cilíndrica, reta; cotilédo. nes foliáceos, planos quase alcançando $\mathrm{c}$ tamanho da radícula.

DISTRIBUIÇÃo GEOGRÁFICA - América : Colômbia, Venezuela, Guianas e região Amazônica do Brasil.
ESPÉCIE TÍPICA - Sterigmapetalum obovatum Kuhlmann.

\section{CHAVE PARA IDENTIFICAC̣ÃO DAS ESPÉCIES DE STERIGMAPETALUM}

1. Inflorescência corimbosa; pedúnculos $3-6 \mathrm{~cm}$; flores externamente denso tomentosas.

1. S. obovatum

1. Infloroscência em pequenas umbelas; pedúnculos $1-3 \mathrm{~cm}$; flores externamente pubérulas ou esparsamente tomentelas.

2. Margem das folhas inteira; estipulas pubérulas; óvulo esparsamente pubérulo; pedúnculos pubérulos.

\section{S. colombianum}

2. Margem das folhas glandular-denticulada ou quase inteira; estipulas densamente seríceas; óvulo hirsuto; pedúnculos temantelos.

3. S. guianense 
1. Sterigmapetalum obovatum Kuhlmann

Arch. Jard. Bot. Rio de Janeiro, 4: 360. 1925.

НÁвIто - Árvore pequena a grande, ramos fortes, 3-5 verticilados, densamente cinzento-velutinos, quadrangulares.

FOLHAS - 3-5 verticiladas, curto-pecioladas; pecíolo piloso, $0,5-2 \mathrm{~cm}$ de comprimento; lâminas jovens frouxamente furfuráceas quando adultas, glabras na face superior, com nervuras primárias e secundárias levemente pilosas na face inferior, obovado-obtusas ou levemente agudas, ou brevemente truncado-emar. ginadas no ápice, $9-17 \mathrm{~cm}$ de comprimento e 4,5-9 $\mathrm{cm}$ de largura, peninérveas; nervuras em ambos os lados 11-15, nervura mediana, proeminentes na face inferior, ereto-patentes lereto-abertas), com o ápice levemente curvado; vênulas reticuladas, prominulas em ambos os lados.

INFLORESCÊNCIA - Subterminal, corimbosa, dicotômica dividida, nas axilas das folhas superiores, longo-pedunculada; pedúnculos, pedicelos e cálices densamente curto-seríceos; pedúnculo $3-6 \mathrm{~cm}$ de comprimento, bracteolado; bractéolas curtissimas, subulados, vilosas.

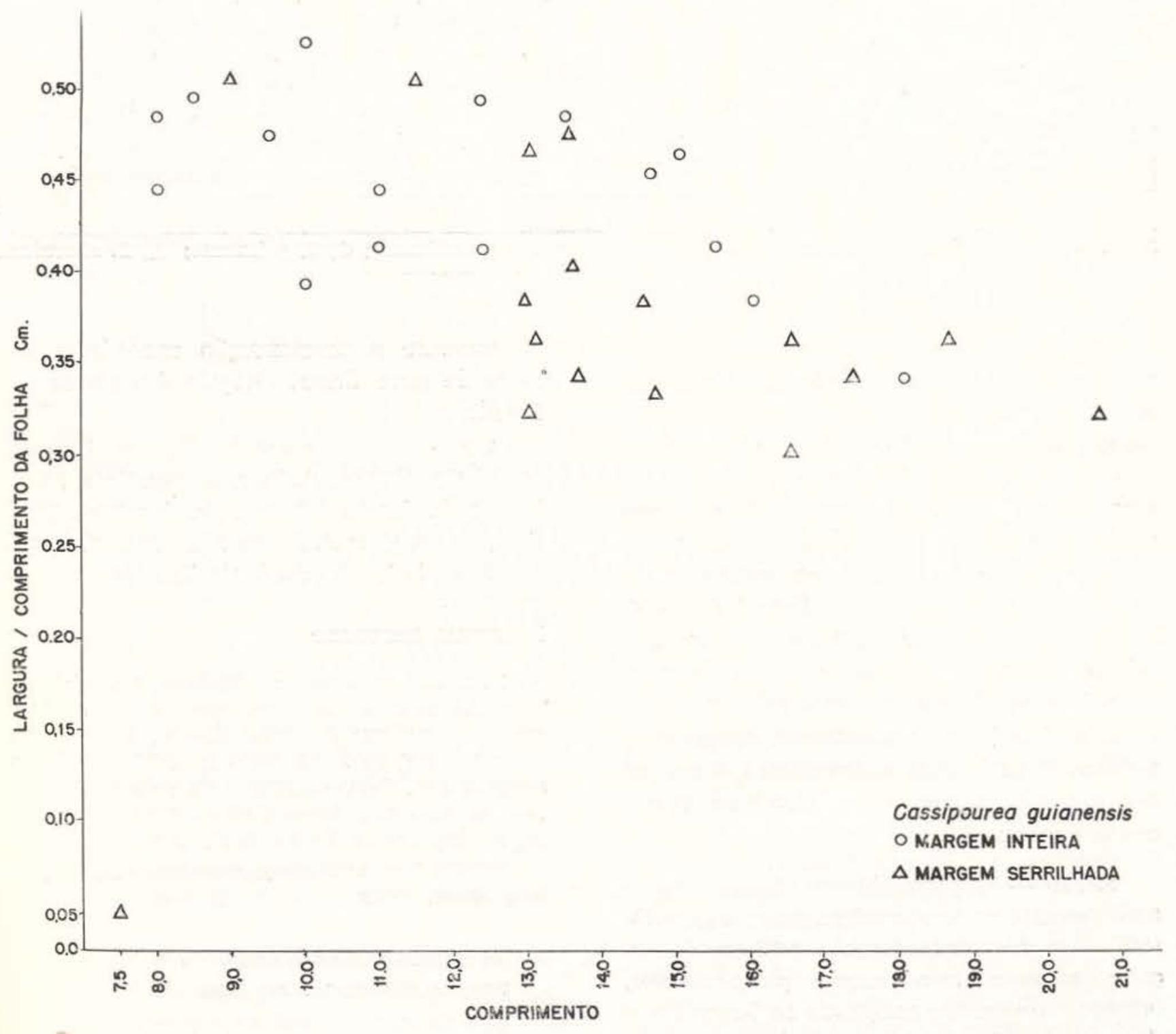

Gráfico. 2. Diagrama pictórico de variação de Cassipourea guianensis Aubl.: - Razão, largura/compri. mento de folha, comprimento de folha e tipo de margem. Os diagramas mostram claramente que baseado nas características analisadas (aquelas usadas pelos autores anteriores para distinguir a nova espécie), Cassipourea serrata não é distinta e nem merece ser reconhecida como variedade taxonômica. 


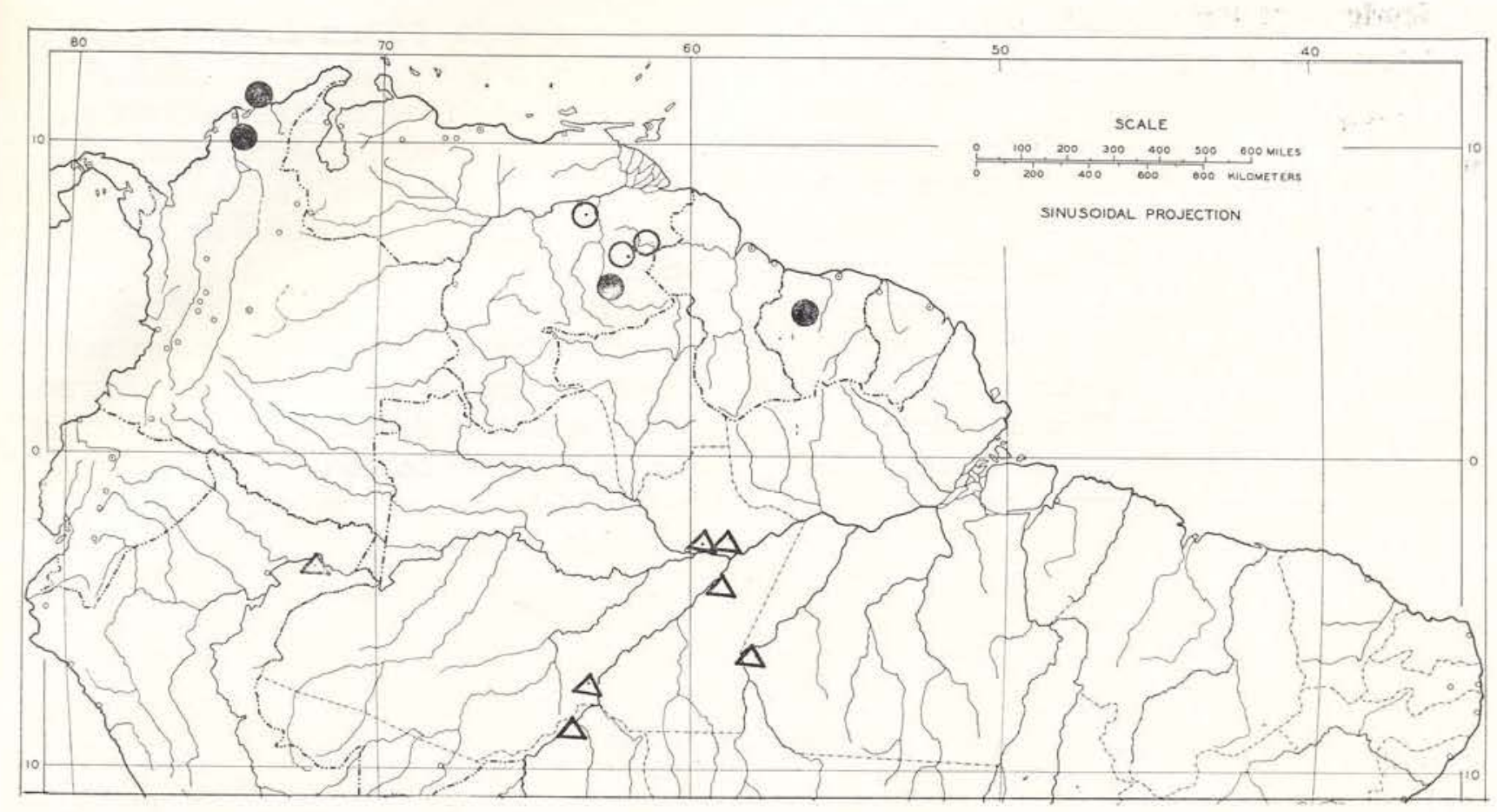

Mapa 4. Distribuição do gênero Sterigmapetalum. S. colombianum; O, S. guianense; $\Delta$, S. obovatum.

FLORES - Flores masculinas sésseis; flores femininas curtamente pediceladas $2 \mathrm{~mm}$ de comprimento; cálice das flores masculinas 5-6 mm de comprimento, 3-4 mm de largura; cálice nas flores femininas após a fecundação, acrescentes, 5-6 $\mathrm{mm}$ de comprimento e 7-8 $\mathrm{mm}$ de largura; dentes triangulares, frouxamente seríceos por dentro; pétalas em ambos os sexos lineares, flageliformes-lacinuladas, 10$12 \mathrm{~mm}$ de comprimento e $1,5 \mathrm{~mm}$ de largura, inflexas na antese, glabras; estames $4 \mathrm{~mm}$ de comprimento, glabros, com anteras ovadas, cord:adas na base; ovário rudimentar, densamente seríceo; estaminódios rudimentares, $1 \mathrm{~mm}$ de comprimento; ovário da flor feminina densamente seríceo.

FRUTO - Cápsula oblongo-obovada, densa e brevemente serícea, perfeitamente desenvolvida, $4 \mathrm{~cm}$ de comprimento e $2-2,5 \mathrm{~cm}$ de largura; semente com nucela plano-convexa, oblonga, curtamente estipitada na base, $8 \mathrm{~mm}$ de comprimênto e 3,5-4 $\mathrm{mm}$ de largura, castanha, com alas mebranáceas oblongo-falciformes, assimétricas na base, $11 \mathrm{~mm}$ de comprimento e $7-8 \mathrm{~mm}$ de largura.
HABITAT E DISTRIBUIÇÃo GEOGRÁFICA Mata de terra firme. Região Amazônica do Brasil.

TIPO - J. Kuhlmann $375 \mathrm{fl}$. fem. (lectotipo RB 17933) BRASIL. Terr. de Rondônia, Porto Velho; A. Ducke RB $6803 \mathrm{fr}$. (parátipo RB), Pará, rio Tapajós; A. Ducke MG 16422 fl. masc. (parátipo MG, RB) Pará, rio Tapajós.

\section{MATERIAL ESTUdAdo}

BRASIL. Amazonas, rio Madeira, Município de Humaitá, próximo de Livramento, B. A. Krukoff $6798 \mathrm{fl}$. (NY), 7021 fl. (NY); Manaus, A. Ducke RB 23472 fl. (NY, RB), RB 23473 fl. (NY, RB), E. P. Killip \& A. C. Smith 30197 fl. (NY); rio Urubu, igarapé Sangana R. L. Fróes 25448 fl. (IAN, NY); Borba, rio Madeira, A. Ducke 75 fl. (NY).

PERU. Loreto: Mishuyacu próximo Iquitos, G. Klug $897 \mathrm{fl}$. (NY).

2. Sterigmapetalum colombianum Monachino Tropical Woods 77: 10. 1944.

нábito - Árvore cerca de $25 \mathrm{~m}$ de altura, 30-60 cm de diâmetro; ramos jovens densamente pubescentes, pelos deitados, amarelo-pálidos; cicatrizes interpeciolares, lineares. 
FolHas - Ternadas, obovadas, 4,5-6 cm de comprimento e $2-4 \mathrm{~cm}$ de largura, arredondadas ou levemente emarginadas, obscuramente mucronadas no ápice, agudas na base, glabras e brilhantes em ambos os lados, na face inferior com pelos brancos, transparentes, esparsos, sobre as nervuras principal e secundárias, cerca de 11 pares, elevadas na face inferior, quase proeminentes em ambos os lados, subcoriáceas, às vezes com pequenas vesículas na parte inferior das lâminas; pecíolo $2-5 \mathrm{~mm}$ de comprimento, pubescente na base.

INFLORESCÊNCIA - Axilar, próxima às extremidades dos ramos jovens, com poucas flores; pedicelos ca. de $3 \mathrm{~mm}$ de comprimento, densamente adpresso-pubescentes (visto apenas no botão das flores femininas), na extremidade, pentâmero; sépalas esparsamente adpresso-pubescente externamente; pétalas fimbriadas no ápice, com 12 lobos, e um tufo de cerdas eretas, outras veezs glabras; estaminódios 10, escamiformes, unidos na base em um anel, cerca de $0,25 \mathrm{~mm}$ de altura; ovário esferoidal, pubescente, com pelos deitados, 5-anguloso; estilete $0,4 \mathrm{~mm}$ de comprimento; estígma 5-lobado; carpelos 5, óvulos 2 em cada carpelo, unidos no ápice do eixo central.

$$
\text { NOME VULGAR - Popa (Colômbia). }
$$

HABITAT E DISTRIBUição GEOGRÁFICA Mata. Ocorre em Colômbia, Venezuela e Guianas.

TIPo - Espina \& Giacometto A31, Colômbia, Magdalena, Rio Jabali, fl. fem. (holótipo, NY) .

\section{Material estudado}

VENEZUELA. Bolívar: Serra Ichún, Salto Maria Fspuma, J. A. Steyermark $90428 \mathrm{fl}$. (NY).

SURINAME. Tafelberg, B. Maguire $24780 \mathrm{fl}$. (INPA, NY).

\section{Sterigmapetalum guianense Steyermark} Fieldiana Bot, 28 (2): 422, 1952.

HÁBíto - Árvore de 15-23 m de altura, ramos 3-4 verticilados, cilíndricos, os jovens seríceo-pubescentes, os mais velhos glabros.

ESTÍPULAS - Ovado-triangulares com ápi-

(8) - Por Pedro Ivo Braga e Marilene Nogueira Braga. ce obtuso, 6-7 $\mathrm{mm}$ de comprimento, densamente seríceas em ambas as faces.

FOLHAS - 3-4 verticiladas, curto-pecioladas; pecíclo $5-9 \mathrm{~mm}$ de comprimento, glabros; lâminas coriáceas, largamente obovadocuneadas, ou oblongo-elíticas, $3-8 \mathrm{~cm}$ de comprimento, $2-7 \mathrm{~cm}$ de largura, ápice mais ou menos subtruncado-emarginado ou largamente arredondado, glabras ou pubescentes na face inferior, margem ligeiramente glandular-denticulada ou subintegérrimas; nervura mediana, proeminente na face inferior, glabra ou parcialmente adpresso-pubescente; nervuras secundárias em ambos os lados 9-10, arqueado-ascen dentes, venulas denso reticuladas em ambas as faces.

INFLORESCENNCIA - Axilar, subterminal; pedúnculos $1-2 \mathrm{~cm}$ de comprimento, densoseríceos;

Flores femininas: Botão floral $3-4 \mathrm{~mm}$ de comprimento, parcialmente seríceo externamente, densamente na face interna; lobos das pétalas 6-10, ápice densamente híspido, externamente a partir do ápice, densamente seríceo-pubescentes; ovário 5-locular, densamente hirsuto; estígma 5-lobulado.

Flores masculinas: Com 10 estames.

HABITAT E DISTRIBUição GEOGRÁFICA Mata. Ocorre em Venezuela, na base da serra ao longo do rio Kurai, Ptari-tepuí, e rio Cuyuni, Estado de Bolívar.

TIPo - Steyermark 60658, Venezuela, Bolívar, rio Kuruai, fl. (holótipo, F) .

\section{MAterial estudado}

VENEZUELA. Bolívar, Chimantá Massif, fl. (NY); alto rio Cuyuni, B. Maguire et alii $468 \% 6 \mathrm{fl}$. (INPA, NY).

\section{Polygonanthus Ducke $\left(^{8}\right)$}

(Mapa 5)

Notizbl. Bot. Gart. Berlin 11: 345-346. 1932; Arch. Jard. Bot. Rio de Janeiro 6: 62-63. Tab. VII fig. 9. 1933.

(Olacaceae, Croizat (1939); Saxifragaceae, Baehni \& Dansereau (1939); Rhizophoraceae, Kuhlmann (1944). 


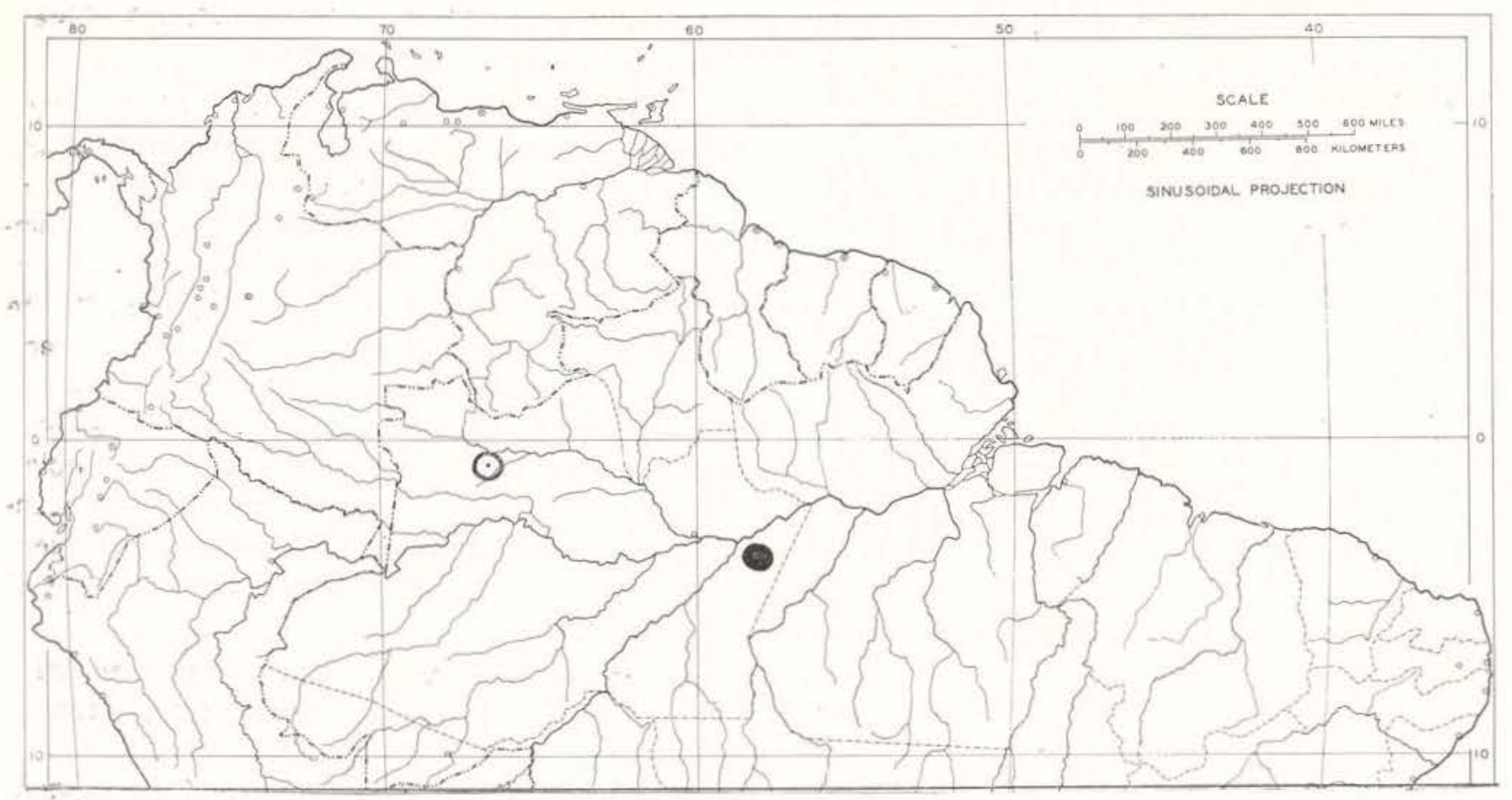

․ Mapa 5. Distribuição do gênero Polygonanthus. O, P. punctulatus; P. amazonicus.

HÁBITO - Árvores.

ESTÍPULAS - Grandes, lanceoladas, caducas.

FOLHAS - Alternas, disticas.

INFLORESCÊNCIA - Nas axilas superiores, interrompidas, rácemos parecendo espigas.

FLORES - Cíclicas, monóicas ou poligamas.

Flores masculinas: Em ráques numerosos, pequenos, subsésseis, verde-albo; cálice 4, raro 5-partido, prefloração valvar, apículo pequeno inflexo; pétalas 4 , sépalas curtas muito delgadas; estames 8 , inseridos no fundo do cálice, livres, exsertos ou não; filetes antes da prefloração com ápice inflexo, complanado, disco glandular pequeno, 8 intraestaminais e 8 interestaminais; pistilo rudimentar, alongado, quadripartido; filetes freqüentemente planos.

Flores femininas: Em menor número; pedicelo de comprimento maior e muito espesso, verde; cálice na antese turbinado, 4 lobos, grandes, venação reticulada, após a antese excrescendo em alas eretas; pétalas pequenas, lanceoladas" ápice subulado no fruto, pouco evidente; estaminóides 8 , com anteras pequenas; filetes no fruto, mais ou menos persistentes, disco quase nulo; ovário formando tubo com o cálice, antes da antese semisúpero, lóculos 4, uni-ovulados; óvulos anátropos, no ápice do lóculo, pendente, após a antese mais inferior; estiletes 4 , conados na base, aumentados e endurecidos no fruto, ápice reflexo, estígma papiloso.

FRUTO - Careniforme com alas alternadas, em pedunculos decurrentes, muito espesso, lenhoso; semente desconhecida; parte seminífera, subpiramidal, 4-angulosa.

HABITAT E DISTRIBUIÇÃo GEOGRÁFICA Margens dos rios da Amazônia brasileira.

ESPÉCIE TÍPICA - Polygonanthus amazonicus Ducke.

\section{CHAVE PARA IDENTIFICAC̣ĀO DAS ESPÉCIES DE POLYGONANTHUS}

1. Folhas sem pontuações; estames exsertos.

$$
\text { 2. P. amazonicus }
$$

1. Folhas com pontuações; estames não exsertos.

$$
\text { 2. P. punctulatus }
$$

\section{Polygonanthus amazonicus Ducke.}

Notizbl. Bot. Gart. Berlin 11: 346. 1932., Arch. Jard. Bot. Rio de Janeiro 6: 62-63. Tab. VII. Fig. 9. 1933; J. Pires \& W. A. Rodrigues, Acta Amaz. 1 (2): 7-15. 1971. 
нÁвIто - Arvore de altura média, tronco com base muito grossa; ramos avermelhados rugoso-estriados, freqüentemente lenticelosos, híspidos.

FOLHAS - Oblongas ou ovado-lanceoladas, $5-75 \mathrm{~cm}$ de comprimento e $15-35 \mathrm{~cm}$ de largura; base aguda, ápice semiacuminado; margem ondulada, na face dorsal esbranquiçadas, tenuemente peninérveas; venulas na face dorsal distintamente promínulas.

INFLORESCÊNCIA - Racemosa, até $6 \mathrm{~cm}$ de comprimento, ráque ininterruptamente carregado de flores, delgado, pubérulo; bráctea membranácea.

Flores masculinas: Botões ovais de apenas $2 \mathrm{~mm}$ de comprimento, $5 \mathrm{~mm}$ de diâmetro; segmentos do cálice externamente pubérulos e internamente glabros; pétalas subglabras com a margem ciliada.

Flores femininas: Solitárias na antese; ápice dos lobos do cálice pouco pubérulos; pétalas com margem ciliada.

FRUTO - Com alas de $2,5 \mathrm{~cm}$ de comprimento e $1 \mathrm{~cm}$ de largura, tubo do cálice com $1,5 \mathrm{~cm}$ de comprimento e $2 \mathrm{~cm}$ de espessura.

TIPO - A. Ducke RB 23650, Brasil, Amazonas, Maués, fl. (holótipo, RB) .

HABITAT E DISTRIBUIÇÃO GEOGRÁFICA Beira do rio em praias alagadas. Conhecido somente perto de Maués, Amazonas.

\section{MATERIAL ESTUdAdo}

BRASIL. Amazonas: Maués, J. M. Pires $53 \mathrm{fl}$. (IAN, INPA 5449, NY), 1281 fl. (IAN, INPA 16082, NY).

\section{Polygonanthus punctulatus Kuhlmann}

An. Prim. Reun. Sul. Amer. Bot. 3: 80. 1910; Pires \& Rodrigues, Acta Amaz. 1 (2): 7-15. 1971.

на́вIто - Árvore pequena (ex. A. Ducke), ramos maiores e menores dísticos, próximos uns dos outros, parte superior cinza, pubescentes, inferior castanha; ramos jovens e adultos glabros, estes com rugas longitudinais.

(9) - Por Izonete Araújo e Raimunda C. Q. Vilhena
FolHas - Lâmina 5-9 raro $9,5 \mathrm{~cm}$ de comprimento, $12-40 \mathrm{~mm}$ de largura, oblongo-lanceolada ou oblongo-elítica; ápice subacuminado, obtuso, rígido, amarelada em ambas as faces, parte superior brilhante ou opaca (material herborizado), margem pouco revolta; face inferior densamente pontuada, pontuações negras; nervuras secundárias de ambos os lados promínuias, mais no dorso do que na face superior, em ambos os lados, 6-9, alternando com as menores.

INFLORESCÊNCIA - Monóica ou polígama, 2-3,5 cm de comprimento, ráque espesso; brảctea ovado-oblonga, hirsuta externamente, com margem ciliada.

\section{FLORES - Masculinas e femininas.}

Flores masculinas : Obovais, $3 \mathrm{~mm}$ de comprimento e largura, externamente glabras, lobos do cálice sublenhosos, espessos, ápice internamente apendiculado, apendice filitorme inflexo; pétalas com base atenuada, subcuculado-espatuladas, ápice obtuso subtruncado, externa e internamente papilosas, espessas na margem, $1 \mathrm{~mm}$ de comprimento e largura; estames insertos; antera orbicular; filetes glabros com base dilatada e oposta às glandulas em ambos os sexos com margem papilosa.

Flores femininas: Glabras, $10 \mathrm{~mm}$ de comprimento; pétala deltóide-ovoide, $2 \mathrm{~mm}$ de comprimento; papilas pequenas, dorso carinacio; estaminódios e 1 estilete glabros; ovário glabro.

FRUTO - Desconhecido.

HABITAT E DISTRIBUIÇÃo GEOGRÁFICA Beira do rio. Conhecido somente no rio Curicuriari, na região do alto rio Negro.

TIPo - A. Ducke RB 37727 (holótipo, RB; isótipo, INPA), Brasil, Amazonas, rio Curicuriari.

\section{Anisophyilea R. Brown ex Sabine $\left({ }^{9}\right)$ (Mapa 1)}

In Trans. Hort. Soc. 5:446.1824.

HÁBITO - Árvore ou arbusto.

estíPUlas - Presentes, caducas.

FOLHAS - Simples, alternas. 
INFLORESCÊNCIA - Panícula, axilar ou supraxilar, com ou sem bractéeolas.

FLORES - Hermafroditas ou unissexuais por aborto, pequenas, actinomorfas, com brácteas; presença de disco; cálice com tubo adnado ao ovário; sépalas 4 , valvares; pétalas 4-lobadas, laciniadas ou inteiras; estames 8, epipétalos; anteras dorsifixas, pequenas; unicarpelar; ovário ínfero, tetralocular, um óvulo para cada lóculo, anátropo, pendente; placentação axilar; estiletes 4 , dilatados na base em disco hipógino.

FRUTO - Baga ou drupa; semente 1, albume nu, cotilédones nus, pequenos.

DISTRIBUIÇÃo GEOGRÁfICA - Velho Mundo Tropical, África, Ásia, Arquipélago Malaio, e no Novo Mundo, no Amazonas e Guianas.

ESPÉCIE TÍPICA - Anisophyllea laurina R. Brown ex Sabine.

\section{CHAVE PARA IDENTIFICAC̄ÃO DAS ESPÉCIES AMERICANAS DE ANISOPHYLLEA}

1. Folhas ovado-lanceoladas, geralmente assimétricas, inflorescência axilar e supra-axilar.

\section{A. manausensis}

1. Folhas ovadas, ovado-oblongas, ou ianceoladooblongas, simétricas, inflorescência axilar e terminal.

\section{A. guianensis}

1. Anisophyllea manausensis Pires \& Rodr. Acta Amazonica 1(2):7-13 . 1971

HÁBITO - Árvore grande.

FolHas - Subsésseis, pubescentes, depois glabras, curvinérveas, ovado-lanceoladas, geralmente um tanto assimétricas, delgadas cartáceas, discolores, face superior escura quando secas; base obtusa; ápice agudo-acuminado $9-17 \mathrm{~cm}$ de comprimento por $4,5-7,5 \mathrm{~cm}$ de largura; margem inteira, um tanto revoluta; nervura principal promínula na face superior, proeminente na face inferior; nervuras secundárias 4-7, 1-2 pares saindo da base, promínulas na face superior; proeminentes na face inferior; pecíolo subtereto, $2 \mathrm{~mm}$ de comprimento, 1,5-2 $\mathrm{mm}$ de diâmetro.

ESTÍPUlas - Presentes, caducas.
INFLORESCÊNCIA - Panícula axilar, até $8 \mathrm{~cm}$ de comprimento, pubescente.

Flores - Unissexuais, masculinas, pequenas, solitárias, sésseis, tetrameras, bractéolas na base, 0,5-1,0 mm de comprimento, pubescentes; sépalas 4 , ovadas, valvares, pubescentes, papilosas internamente, $1,35 \mathrm{~mm}$ de comprimento, $1,0 \mathrm{~mm}$ de largura; pétalas 4, raro 5 , convolutas microscopicamente papilosas e ciliadas, $5 \mathrm{~mm}$ de comprimento, 0,3 $\mathrm{mm}$ de largura, pubescentes; estames 8, subiguais, $0,7-1,0 \mathrm{~mm}$ de comprimento; anteras dorsifixas, rimosas; disco sinuoso, lobado.

FRUTO - Drupa, pericarpo externamente coriáceo, internamente de consistência óssea; semente 1 , cotilédones 2 .

HABITAT E DISTRIBUIÇÃO GEOGRÁFICA Mata da terra firme do Estado do Amazonas.

TIPo - W. A. Rodrigues 7211 (holótipo INPA 16114, isótipo MG 31783) .

\section{IVIATERIAL ESTUDADO}

BRASIL. Amazonas: Estraca Manaus-Itacoatiara, W. A. Rodrigues et alii 7242 (INPA 16176), 7665 (INPA 16970), 7672 (INPA 16977), 8466 (INPA 20979), 8690 (INPA 27862), E. Oliveira 2774 (IAN); rio Demeni, Samaúma, R. L. Fróes 28378 (IAN).

\section{Anisophyllea guianensis Sandwith} Kew Bull. 1952: 305. 1952.

HÁBITo - Árvore pequena ou mediana, ramo tereto, glabro ou pouco pubescente, geralmente não lenticelado.

FOLHAS - Ovadas, ovado-oblongas ou oblongo-lanceoladas, ápice agudo, acuminado; base obliqua, desigual, cuneada ou rotunda, $8-17 \mathrm{~cm}$ de comprimento, $2,8-7 \mathrm{~cm}$ de largura, coriácea, glabra em ambos os lados, brilhantes, secas, verde-olivácea; nervura principal canaliculado-achatada na face superior, proeminente na face inferior; nervuras secundárias 5-7 plinérvea na base, canaliculado-achatadas na face superior, proeminentes na face inferior; pecíolo curto, $2.4 \mathrm{~mm}$ de comprimento, glabro.

INFLORESCENCIA - Axilar, terminal; ramos axilares $5-8 \mathrm{~mm}$ de comprimento.

Flores masculinas: Inferiormente ramosas, delgadas, sinuosas, até $15 \mathrm{~cm}$ de comprimen- 
to; ramificações muito curtas, esparsamente pubescentes ou glabrescentes.

Flores femininas: Em cimeiras, axilares, simples, robustas; brácteas estreitamente deltóide-lanceoladas ou quase ovadas, agudas glabrescentes ou mais ou menos ciliadas.

\section{FLORES -}

Flores masculinas: Sésseis, densamente pubescentes; sépalas 4, ovado-agudas, 1,3$1,5 \mathrm{~mm}$ de comprimento, e, 1-1,2 $\mathrm{mm}$ de largura, pubescentes; pétalas 4 , lacínias inclusas, $4,5 \mathrm{~mm}$ de comprimento, $0,3 \mathrm{~mm}$ de largura na parte inferior, margem pubescente-pilosa, abaixo da metade dividida em 3 lacínias sinuosas, muito frágeis; estames 4 , glabros $0,5 \mathrm{~mm}$ de comprimento por $0,3 \mathrm{~mm}$ de largura; disco sinuoso-lobado; estilete densamente pubescente.

Flores hermafroditas ou pelo menos as flores superiores, com o tubo de cálice ovóide-elítico, contraído na região superior do ovário, 2-3mm de comprimento por 1,5-2 $\mathrm{mm}$ de largura, pelos e papilas amareladas, subseríceo, pubescente; sépalas 4 , ovadas, agudas ou acuminadas, $1,5-2 \mathrm{~mm}$ de comprimento por $1,3-1,5 \mathrm{~mm}$ de largura, carnosas, pubescentes em ambos os lados; pétalas 4, alvas, 5-6mm de comprimento, estreitamente lineares na região inferior, $0,3 \mathrm{~mm}$ de larguia, papiloso-pubescentes, a partir da metade dividida em 3 lacínias filiformes, sinuosas, fragilíssimas, pouco pilosas na face inferior, até $3 \mathrm{~mm}$ de comprimento; estames glabros, de 0,5-0,75 mm de comprimento, 4 livres, 4 epipétalos inseridos um pouco acima das pétalas; estiletes $3-4$, triangulares, subulados, $0,5-0,75 \mathrm{~mm}$ de comprimento, mais ou menos unidos na base, inferiormente pubescentes, dilatados, ápice levemente recurvado; óvulos 3-4.

FRUTO - Obliquamente ovóide, pericarpo tênue.

DISTRIBUIÇÃo GEOGRÁFICA - Conhecida somente no rio Potaro na Guiana.

TIPO - D. B. Fanshawe Forest Dept. 3760, Guiana, fl. (K).

marátIPO - Guiana; D. B. Fanshawe Dept. 3912 fl. (K) 4246 botão (K).

\section{PALINOLOGIA DE RHIZOPHORACEAE DA AMAZONIA $\left({ }^{10}\right)$}

\section{INTRODUÇÃo}

O estudo da morfologia dos grãos de pólens das espécies da família Rhizophoraceae, até o momento parece restringir-se apenas às espécies asiáticas e africanas (Erdtman, 1966). Nenhuma outra referência foi encontrada sobre as espécies existentes no Brasil. Este trabalho refere-se à estrutura do pólen de 7 espécies da Amazônia.

\section{Material estudado}

An'sophyllea manausensis Pires \& Rodr., W. Rodrigues 7211 (INPA 16114); Cassipourea guianensis Aubl., L. Coêlho 141 (INPA 35173); Cassipourea peruviana Alston, G. T. Prance et alii 8349 (INPA 25147); Rhizophora harrisonii Leechman, N. T. Silva 172 (INPA 4853); Rhizcphora mangle L., E. L. Little \& R. Dixon 21161 (NY); Sterigmapetalum colombianum Monachino, B. Maguire 24780 (NY); Sterigmapetalum obovatum Kuhlmann, A Ducke RB 23472 (INPA) .

MÉTODO - Empregou-se a técnica da acetólise (Erdtman, 1966), e as mensurações foram feitas em microscópio e as microfotografias em microscópio e máquina fotográfica Nikon.

\section{CARACTERÍsticas DAS ESPÉCIES}

Rhizophora mangle L. - Grão isolado ,tricolporado, $17 \times 10 \mu$, parede intectate, sem grânulos, espessura da parede $21 \mu$.

Rhizophora harrisonii Leechman - Grăo isolado, triaberturado, $17,5 \times 14 \mu$, parede intectate, sem grânulos, espessura da parede $21 \mu$.

Cassipourea guianensis Aubl. - Grão isolado, tricolporado, $10,5 \times 7 \mu$, parede tectate sólida, $5 \mu$ de altura.

Cassipourea peruviana Alston. - Grão isolado, tricolporado, $11,2 \times 12,6 \mu$, parede tectate sólida, $7 \mu$ de espessura.

(10) - Por Pedro Nonato Conceiçăo e Pedro Braga Lisboa. 
Sterigmapetalum colombianum Monach. Grão isolado tricolporado, $14 \times 12 \mu$, parede tectum perforatum, $12 \mu$ de espessura.

Anisophyllea manausensis Pires \& Rodr. Grão sempre em tétrades, tricolporado, parede intectate, sem grânulos, parede $35 \mu$ de espessura.

\section{PÓLEN - CHAVE PARA IDENTIFICAC̣ÃO DOS GENEROS}

1. Grãos isolados, tricolporados, parede tectate ou intectate.

2. Grãos isolados, espessura da parede nunca maior que $10 \mu$, parede tectate sólido.

\section{Cassipourea}

2. Grãos isolados, espessura da parede sempre maior que $10 \mu$, parede tectate ou intectate.

3. Grãos isolados, parede tectate perforatum.

\section{Sterigmapetalum}

3. Grãos isolados, paredes intectate, sem grânulos.

\section{Rhizophora}

1. Grão em tétrade, parede intectate, sem grânulos.

\section{Anisophyllea}

\section{SUMMARY}

A taxonomic revision of the Amazonian species of Rhizophoraceae was made. There are 5 genera and 12 species represented in the area. No new taxa were found and several existing names were reduced to synonomy. Comments are given on the relationship of various species and the distribution of each species is given on maps. Some information about the polen grains is given too

\section{Bibliografia Citada}

ALston, A. H. G.

1925 - Revision of the genus Cassipourea. Kew Bull., 1925:241-270.

AUBLET, F.

1775 - Cassipourea. P1. Guiane., 1:528-530, t. 211.

B.EHNi, C. \& DANSEREAU, P.

1939 - Polygonanthus genre de Saxifragaceae. Bull. Sec. Bot. France, 86: 183-186.

BENTHAM, G.

1840 - Rhizophoreae in: Plants of Schomburgk. Hook. Jour. Bot., 2: 233.

BRETEler, F. G. 1969 - The Atlantic species of Rhizophora. Acta Bot. Neerl., 18(3): 434-441.

BRIQUET, J. 1931 - Rhizophoraceae. Candollea, 4: 342-350.

Croizat, L. M. C.

1939 - Polygonanthus (Olacaceae). Bull. Soc. Bot. France, 86: 5-7.

DING HOU

1960 - A review of the genus Rhizophora. Blumea, 10 (2): 625-634.

ENGLeR, A.

1876 - Rhizophoraceae In: Martius - Fl. Bras., 12 (2): 424-432.

ERDTMAN, G.

1966 - Pollen morphology and plant taxonomy. Angiosperms. New York \& London. $533 \mathrm{p}$.

KEAY, R. W. J,

1953 - Rhizophora in West Africa. Kew Bull., 1953: 121-127.

KUHLMANN, J. G. 1944 - Nota prévia. Rodriguesia, 8 (17): 65 .

LEECHMANN, A.

1915 - The genus Rhizophora in British Guiana. Kew Bull., 1915: 4-7.

PIRES, J. M. \& RODRIGUes, W. A.

1971 - Notas sobre os gêneros Polygonanthus e Anisophyllea. Acta Amazonica, Manaus, 1 (2): 7-15. 